Resumo

\title{
Altura de queda ótima em treinamento pliométrico para equipes de Pentatlo Militar
}

Rafael da Cruz Correia Bsci, Miguel Charbel BSci

Introdução: O Pentatlo Militar é uma modalidade esportiva disputada em cinco provas distintas e dias consecutivos, uma delas é a Pista de Pentatlo Militar. Devido à modalidade não ser praticada por militares com fins predominantemente esportivos, houve pouco interesse da comunidade científica em abordar esse campo de pesquisa. Com a profissionalização do esporte nas forças armadas cresce de importância a pesquisa científica acerca do Pentatlo Militar.

Objetivo: 0 presente estudo averiguou relações entre altura de queda ótima, tempo de contato com o solo após a queda livre, o tempo de voo após o salto e os tempos de execução da pista de pentatlo militar das atletas da equipe feminina brasileira.

Métodos: Participaram deste estudo quatro mulheres saudáveis $(29,25 \pm 2,5$ anos; $61,81 \pm 6,74 \mathrm{~kg}, 171,37 \pm 9,92 \mathrm{~cm}$ ), sem histórico de lesão nos membros inferiores nos últimos seis meses. As atletas realizaram três saltos em quatro alturas de queda selecionadas, com livre utilização dos membros superiores para a execução do salto após a queda. As variáveis do salto foram medidas por uma plataforma de força, utilizando-se o apoio bipodal sobre a plataforma na queda inicial e secundária, dando-se um intervalo de dois minutos entre os saltos nas alturas de queda selecionadas. Os valores encontrados para cada atleta foram comparados através dos testes de correlação de Spearman e Friedman.

Resultados: Duas atletas apresentaram resultados significantes na correlação entre altura de queda e tempo de voo $\left(x^{2}(3,3)=6,52, p=0,09\right.$ e $\left.x^{2}(3,3)=7, p=0,7\right)$. Duas atletas apresentaram resultados significantes na correlação entre altura de

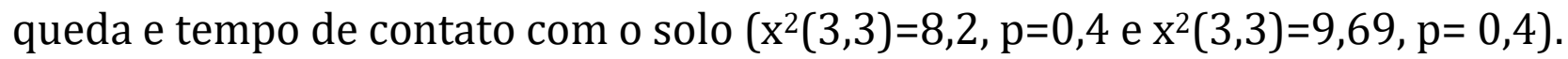
Conclusão: Apesar de ter sido encontrado amparo estatístico para determinar a altura de queda ótima de duas das atletas, não se pode generalizar as conclusões encontradas a todos pentatletas devido à forte individualidade do treinamento pliométrico. 